Original Paper

Pediatr. Endocrinol. 2017.16.2.59:87-94
Stężenie chemeryny u dzieci z cukrzycą typu 1 - doniesienie wstępne

\section{Chemerin concentration in children with type 1 diabetes}

\author{
${ }^{1}$ Agnieszka Zubkiewicz-Kucharska, ' Joanna Chrzanowska, 'Monika Seifert, \\ ${ }^{1}$ Barbara Salmonowicz, ${ }^{2}$ Barbara Chrzanowska, ${ }^{1}$ Anna Noczyńska
}

${ }^{1}$ Katedra i Klinika Endokrynologii i Diabetologii Wieku Rozwojowego Uniwersytet Medyczny we Wrocławiu, ${ }^{2}$ Studenckie Koło Naukowe przy Katedrze i Klinice Endokrynologii i Diabetologii Wieku Rozwojowego, Uniwersytet Medyczny we Wrocławiu

\section{Słowa kluczowe}

chemeryna, cukrzyca typu 1, wyrównanie metaboliczne

\section{Streszczenie}

Wstęp. Chemeryna (CHEM) jest czynnikiem chemotaktycznym, który promuje rekrutację komórek immunologicznych do miejsca uszkodzenia. Wykazywano, że nasila insulinooporność i nietolerancję glukozy, a jej stężenie koreluje z glikemią i stężeniem lipidów. Celem badania jest ocena stężenia CHEM u dzieci z cukrzycą typu 1 (DM1) w zależności od jej wyrównania i czasu trwania. Materiał i metody._Do badania włączono 80 dzieci w wieku 4-18 lat $(x=12,6 \pm 3,6)$ w następujących grupach: dzieci z DM1 rozpoznaną $<2$ lat $(N=23)$, dzieci z DM1 chorujące 2-5 lat $(\mathrm{N}=12)$, dzieci z DM1 chorujące $>5$ lat $(\mathrm{N}=27)$ oraz dzieci bez zaburzeń gospodarki węglowodanowej i chorób autoimmunologicznych (kontrola, $\mathrm{N}=18$ ). Wykonano jednolity komplet badań w celu rozpoznania i ustalenia stopnia wyrównania cukrzycy (m.in. HbA1c, lipidogram, CRP, albuminy w moczu porannym, badanie dna oka w poszukiwaniu retinopatii) i zaawansowania procesu zniszczenia wysp trzustkowych (peptyd c). Ponadto oznaczono stężenia następujących czynników: CHEM, selektyna E, adiponektyna, leptyna, IFN-gamma. Wykonano pomiary antropometryczne. Wyniki. Stężenie CHEM było porównywalne w grupie DM1 do grupy kontrolnej $(55,65 \pm 10,08$ vs. $61,40 \pm 16,65 \mathrm{ng} / \mathrm{ml}$, $\mathrm{p}=0,07)$, podobnie jak stężenie leptyny $(6,27 \pm 7,20$ vs. $10,62 \pm 13,86 \mathrm{ng} / \mathrm{ml}, \mathrm{p}=0,08)$ i IFN- $\gamma(2,99 \pm 3,45$
${ }^{1}$ Department of Endocrinology and Diabetology for Children and Adolescents, Wrocław Medical University, ${ }^{2}$ Student Research Circle at the Department of Endocrinology and Diabetology for Children and Adolescents, Wrocław Medical University

\section{Key words}

chemerin, type 1 diabetes, metabolic control

\section{Abstract}

Introduction. Chemerin (CHEM) is achemotactic factor. It promotes the recruitment of immune cells to the site of injury. It was demonstrated that CHEM increases insulin resistance and glucose intolerance, and its concentration correlates with blood glucose and lipid levels. The aim of the study is to evaluate the concentration of CHEM in children with type 1 diabetes mellitus (T1D) depending on metabolic control and the duration of the disease. Material and Methods. The study included 80 children aged 4-18 years $(x=12.6 \pm 3.6)$ in the following groups: children with T1D diagnosed $<2$ years $(N=23)$, children with T1Ddiagnosed 2-5 years ago $(\mathrm{N}=$ 12), children with T1D for $>5$ years $(N=27)$ and children with no evidence of hyperglycemia or any autoimmune diseases (controls, $\mathrm{N}=18$ ). Laboratory tests were performed to diagnose diabetes and to determine the metabolic control (including $\mathrm{HbA} 1 \mathrm{c}$, lipids, CRP, albumin in the urine, fundus examination, c-peptide). Furthermore, the concentrations of the following: CHEM, E-selectin, adiponectin, leptin, IFN-gamma were assessed. Anthropometric measurements were performed. Results. CHEM concentrations were comparable in the T1D andthe control group ( $55.65 \pm 10.08$ vs. $61.40 \pm 16.65 \mathrm{ng} /$ $\mathrm{ml}, \mathrm{p}=0.07)$, as well as leptin (6.27 \pm 720 vs. 10.62 $\pm 13.86 \mathrm{ng} / \mathrm{ml}, \mathrm{p}=0.08)$ and IFN- $\gamma(2.99 \pm 3.45 \mathrm{vs}$.

Adres do korespondencji / Correspondence address:

Agnieszka Zubkiewicz-Kucharska, ul. Chałubińskiego 2a,

50-368 Wrocław, agnieszka.zubkiewicz-kucharska@umed.wroc.pl 
vs. $8,74 \pm 23,83, p=0,07)$. Stężenia adiponektyny i selektyny E były podobne w obu grupach. W grupie pacjentów z DM1 stężenie CHEM nie różniło się w zależności od wieku badanych, czasu trwania cukrzycy, stopnia wyrównania metabolicznego ( $\mathrm{HbA} 1 \mathrm{c}>7,5 \%$ vs. HbA1c $<7.5 \%)$, obecności peptydu c $(>0,1 \mathrm{ng} /$ $\mathrm{ml}$ ) czy obecności dyslipidemii oraz innej choroby autoimmunologicznej. Wykazano korelację CHEM ze stężeniem selektyny $E(r=0,4790, p=0,024)$ oraz liczbą leukocytów $(r=0,4455, p=0,038)$. Nie potwierdzono korelacji stężenia CHEM z odsetkiem HbA1c ani parametrami gospodarki lipidowej. Wnioski. U pacjentów z cukrzycą typu 1 i prawidłową masą ciała nie wykazano związku CHEM z wyrównaniem metabolicznym i czasem trwania choroby.

Endokrynol. Ped. 2017.16.2.59.87-94.

(C) Copyright by PTEiDD 2017

\section{Wstęp}

Zaangażowanie układu immunologicznego w patogenezę cukrzycy typu 1 nie budzi wątpliwości. Wykazano bowiem nie tylko nieprawidłowości w ilości i/lub funkcji limfocytów, ale także większe stężenia prozapalnych cytokin w surowicy krwi pacjentów z cukrzycą typu 1, a także nieprawidłowy profil wydzielanych przez mononukleary cytokin [1-3].

W otyłości, zespole metabolicznym i cukrzycy typu 2 obserwowany jest również toczący się proces zapalny o małym nasileniu. Przerośnięta tkanka tłuszczowa wytwarza adipocytokiny, z których część ma właściwości prozapalne. Insulinooporność nasila ten proces. Wydaje się, że właśnie proces zapalny łączy otyłość i towarzyszącą jej często insulinooporność z chorobami sercowo-naczyniowymi [4-6].

Czy u pacjentów z cukrzycą typu 1 tkanka tłuszczowa także odgrywa rolę $\mathrm{w}$ patogenezie samej choroby i jej powikłań naczyniowych?

Chemeryna (CHEM), znana wcześniej jako TIG2 (tazaroteneinducedgene 2 protein) lub RAR-RES2 (retinoidacid receptor responder 2) jest czynnikiem chemotaktycznym. Wydzielona jest jako nieaktywna forma - prochemeryna. Jest ona aktywowana odszczepieniem c-końcowego peptydu pod wpływem proteaz serynowych lub cysteinowych w kaskadzie układu krzepnięcia, fibrynolizy i zapalenia [7-9].

Wykazano, że różne klasy enzymów proteolitycznych odszczepiają od prochemeryny peptydy
$23.83 \pm 8.74, p=0.07)$. Adiponectin, and E-selectin were also similar in both groups. In patients with T1D CHEM concentration did not vary depending on age, duration of diabetes, the degree of metabolic control (HbA1c> $7.5 \%$ vs. $\mathrm{HbA} 1 \mathrm{c}<7.5 \%)$, the c-peptide presence $(>0.1 \mathrm{ng} / \mathrm{ml}$ ) or the presence of dyslipidemia and other autoimmune disease. CHEM correlated with E-selectin concentration $(r=0.4790$, $p=0.024)$ and the number of white blood cells ( $r=$ $0.4455, p=0.038$. There was no correlation of CHEM concentration with $\mathrm{HbA} 1 \mathrm{c}$ and lipids. Conclusions. No relationship between chemerin concentration and metabolic control as well as duration of the disease was observed innormal weight patients with type 1 diabetes.

Pediatr. Endocrinol. 2017.16.2.59.87-94.

(c) Copyright by PTEiDD 2017

o przeciwstawnych działaniach: neutrofile generują proteazy serynowe, zdolne do produkcji aktywnych peptydów, natomiast proteazy cysteinowe, które są wydzielane przez makrofagi, promują powstanie peptydów hamujących - chemeryny 15. Rozpuszczalna forma chemeryny jest zatem białkiem wielofunkcjonalnym, zdolnym do stymulacji, jak i do hamowania sygnału [9].

CHEM jest czynnikiem chemotaktycznym. Poprzez receptor ChemR23 promuje rekrutację komórek immunologicznych do miejsca uszkodzenia. Jest zdolna do wpływu na procesy zapalne już w pikomolarnych zakresach [7].

Wykazano także, że utrata ekspresji CHEM w preadipocytach poważnie zaburza różnicowanie komórek do dojrzałych adipocytów i redukuje ekspresję genów włączonych w metabolizm glukozy i lipidów, w tym adiponektyny i leptyny. Ponadto CHEM nasila insulinooporność i nietolerancję glukozy. Silny spadek stężenia CHEM towarzyszy spadkowi glikemii i obniżeniu CRP, niezależnie od BMI [10,11].

Badanie Stjeskala wskazuje, że CHEM może być markerem zespołu metabolicznego, bowiem jej stężenie koreluje z glikemią, ciśnieniem tętniczym i stężeniem lipidów [9].

Badania nad rolą tej adipocytokiny w patogenezie cukrzycy typu 1 i jej powikłań naczyniowych nie są liczne [12-14]. Czy poprzez zaangażowanie tkanki tłuszczowej w patomechanizm obu schorzeń cukrzyca typu 1 i 2 może stanowić swego rodzaju kontinuum?

Stężenie chemeryny u dzieci z cukrzycą typu 1 - doniesienie wstępne 
Cel

Celem badania była ocena stężenia CHEM u dzieci z cukrzycą typu 1 (DM1) w zależności od jej wyrównania i czasu trwania.

\section{Pacjenci i metody}

Do badania włączono 80 dzieci w wieku 4-18 lat $(x=12,6 \pm 3,6)$ w grupach: dzieci z DM1 rozpoznaną $<2$ lat $(\mathrm{N}=23)$, dzieci z DM1 chorujące 2-5 lat $(\mathrm{N}=12)$, dzieci z DM1 chorujące $>5$ lat $(\mathrm{N}=27)$ oraz dzieci z prawidłową masą ciała, bez zaburzeń gospodarki węglowodanowej i chorób autoimmunologicznych (kontrola, $\mathrm{N}=18$ ). Rozkład płci i wieku, a także BMI SDS były porównywalne we wszystkich badanych grupach.

Wykonano jednolity komplet badań w celu rozpoznania i ustalenia stopnia wyrównania cukrzycy (m.in. HbA1c, lipidogram, CRP, albuminy w moczu porannym, badanie dna oka w poszukiwaniu retinopatii) i zaawansowania procesu zniszczenia wysp trzustkowych (peptyd c). Oznaczono (ELISA) stężenia następujących czynników: CHEM, selektyna E, adiponektyna, leptyna, interferon $\gamma($ IFN- $\gamma$ ).

Zgodność rozkładu analizowanej próby z rozkładem normalnym sprawdzano testem W Shapiro-Wilka. Do porównywania zmiennych niezależnych wykorzystano test t-studenta lub test U Manna-Whitneya. W celu obliczenia zależności cech stosowano współczynnik korelacji prostoliniowej Pearsona oraz współczynnik korelacji rang Spearmana. Różnicę uznawano za istotną statystycznie przy $\mathrm{p}<0,05$. A priori do badania nie wykonano szacowania wielkości próby, wykorzystywano jednak wszystkie dostępne przypadki.

\section{Wyniki}

Stężenie CHEM było porównywalne w grupie DM1 i w grupie kontrolnej $(55,65 \pm 10,08$ vs. $61,40 \pm 16,65 \mathrm{ng} / \mathrm{ml}, \mathrm{p}=0,07)$, podobnie jak stężenie leptyny $(6,27 \pm 7,20$ vs. $10,62 \pm 13,86 \mathrm{ng} / \mathrm{ml}$, $\mathrm{p}=0,08)$ i IFN- $\gamma(2,99 \pm 3,45$ vs. $8,74 \pm 23,83 \mathrm{pg} /$ $\mathrm{ml}, \mathrm{p}=0,07)$. Stężenia adiponektyny i selektyny $\mathrm{E}$ również były podobne w badanych grupach i wynosiły odpowiednio $9092,13 \pm 4279,0 \mathrm{ng} / \mathrm{ml}$ vs. $8791,06 \pm 5097,05 \mathrm{ng} / \mathrm{ml}, \mathrm{p}=0,80$, i $45,78 \pm 19,46$ $\mathrm{ng} / \mathrm{ml}$ vs. $41,85 \pm 17,02 \mathrm{ng} / \mathrm{ml}, \mathrm{p}=0,45$.

W obu grupach liczba leukocytów, stężenie CRP oraz parametry gospodarki lipidowej były porównywalne.

W grupie pacjentów z DM1 stężenie CHEM nie różniło się $(p>0,05)$ w zależności od czasu trwania cukrzycy, stopnia wyrównania metabolicznego (HbA1c $>7,5 \%$ vs. HbA1c $<7.5 \%$ ), obecności peptydu c $(>0,1 \mathrm{ng} / \mathrm{ml})$ czy obecności innej choroby autoimmunologicznej. Wyniki przedstawiono w tabeli I.

Tabela I. Stężenie chemeryny u pacjentów z cukrzycą typu 1 Table I. Chemerin concentration in patients with type 1 diabetes

\begin{tabular}{|c|c|c|c|}
\hline \multicolumn{4}{|c|}{ Czas trwania cukrzycy } \\
\hline & 0-2 lata & $2-5$ lat & $>5$ lat \\
\hline Chemeryna (ng/ml) & $57,94 \pm 10,67$ & $50,69 \pm 9,61$ & $56,26 \pm 9,35$ \\
\hline \multicolumn{4}{|c|}{ Wyrównanie metaboliczne } \\
\hline & $\mathrm{HbAc1}<7,5 \%$ & $\mathrm{HbA} 1 \mathrm{c}>7,5 \%$ & \\
\hline Chemeryna (ng/ml) & $55,13 \pm 10,58$ & $55,99 \pm 9,88$ & \\
\hline \multicolumn{4}{|c|}{ Zachowana insulinosekrecja } \\
\hline & c-peptyd $>0,1 \mathrm{ng} / \mathrm{ml}$ & c-peptyd $<0,1 \mathrm{ng} / \mathrm{ml}$ & \\
\hline Chemeryna (ng/ml) & $55,67 \pm 10,47$ & $55,39 \pm 9,12$ & \\
\hline \multicolumn{4}{|c|}{ Inna choroba autoimmunologiczna } \\
\hline & Tak & Nie & \\
\hline Chemeryna (ng/ml) & $57,68 \pm 14,48$ & $54,64 \pm 8,10$ & \\
\hline
\end{tabular}




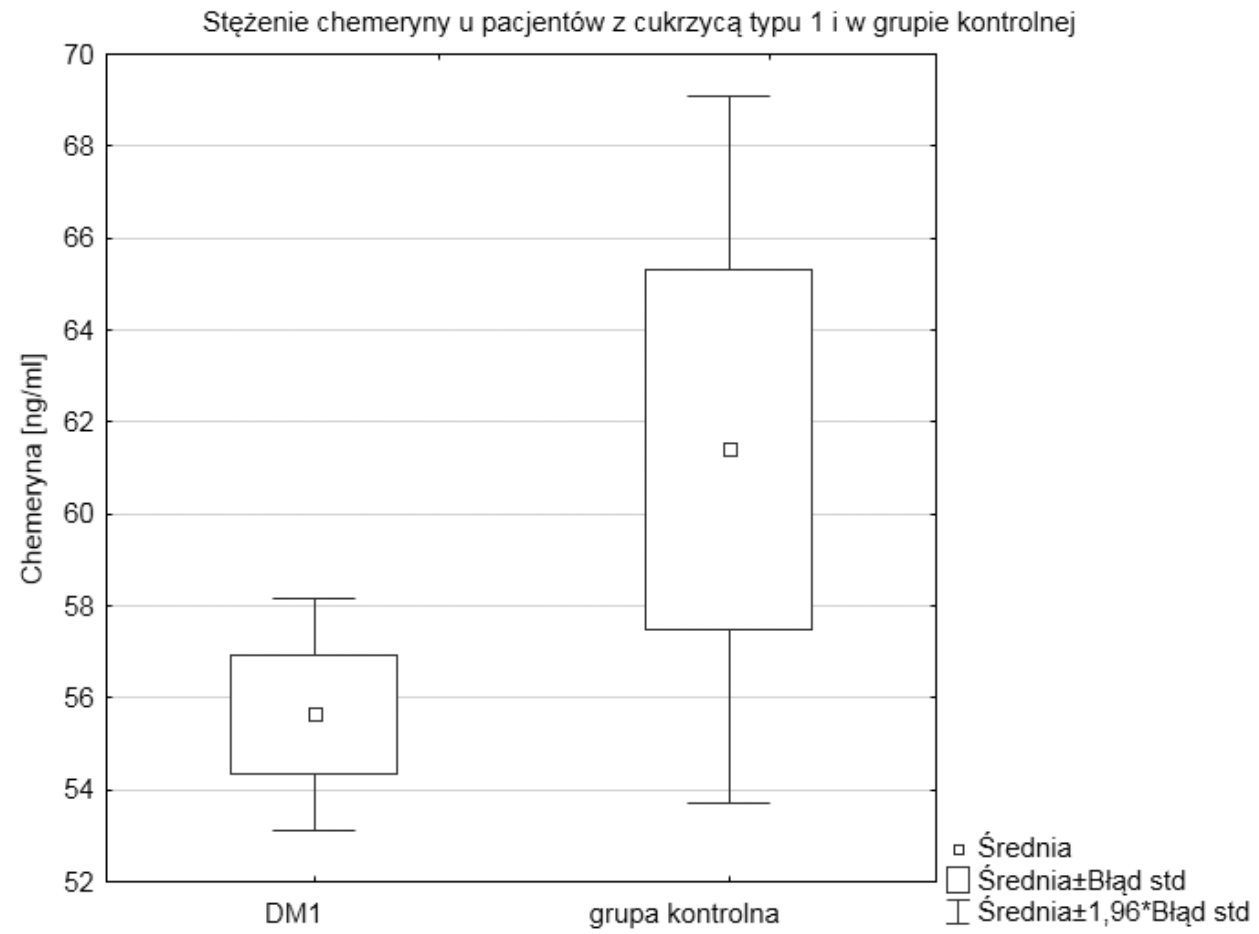

Ryc. 1. Stężenie chemeryny u pacjentów z cukrzycą typu $1 \mathrm{i}$ w grupie kontrolnej

Fig. 1. Chemerin concentration in patients with type 1 diabetes and in controls

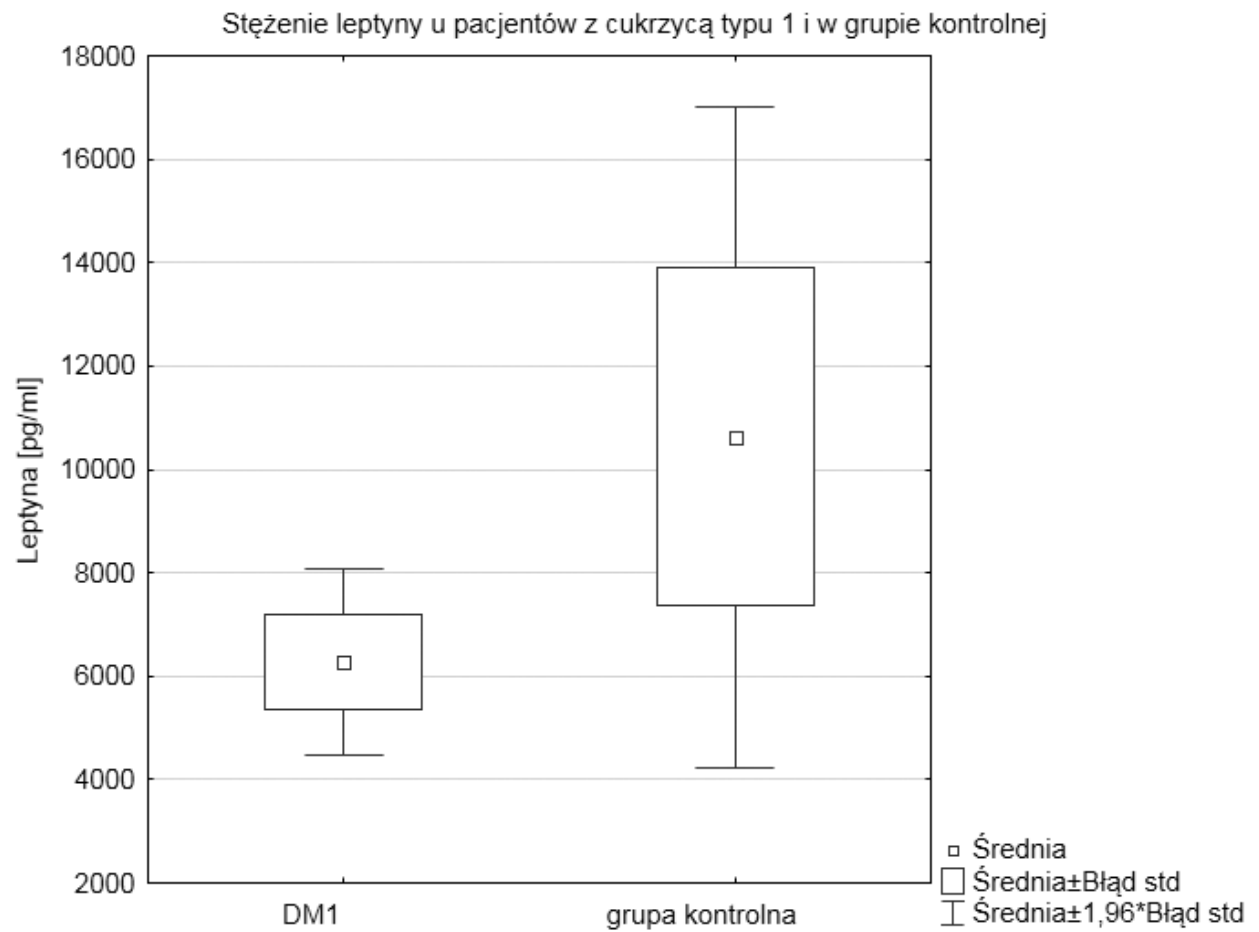

Ryc. 2. Stężenie leptyny u pacjentów z cukrzycą typu 1 i w grupie kontrolnej

Fig. 2. Leptin concentration in patients with type 1 diabetes and in controls 


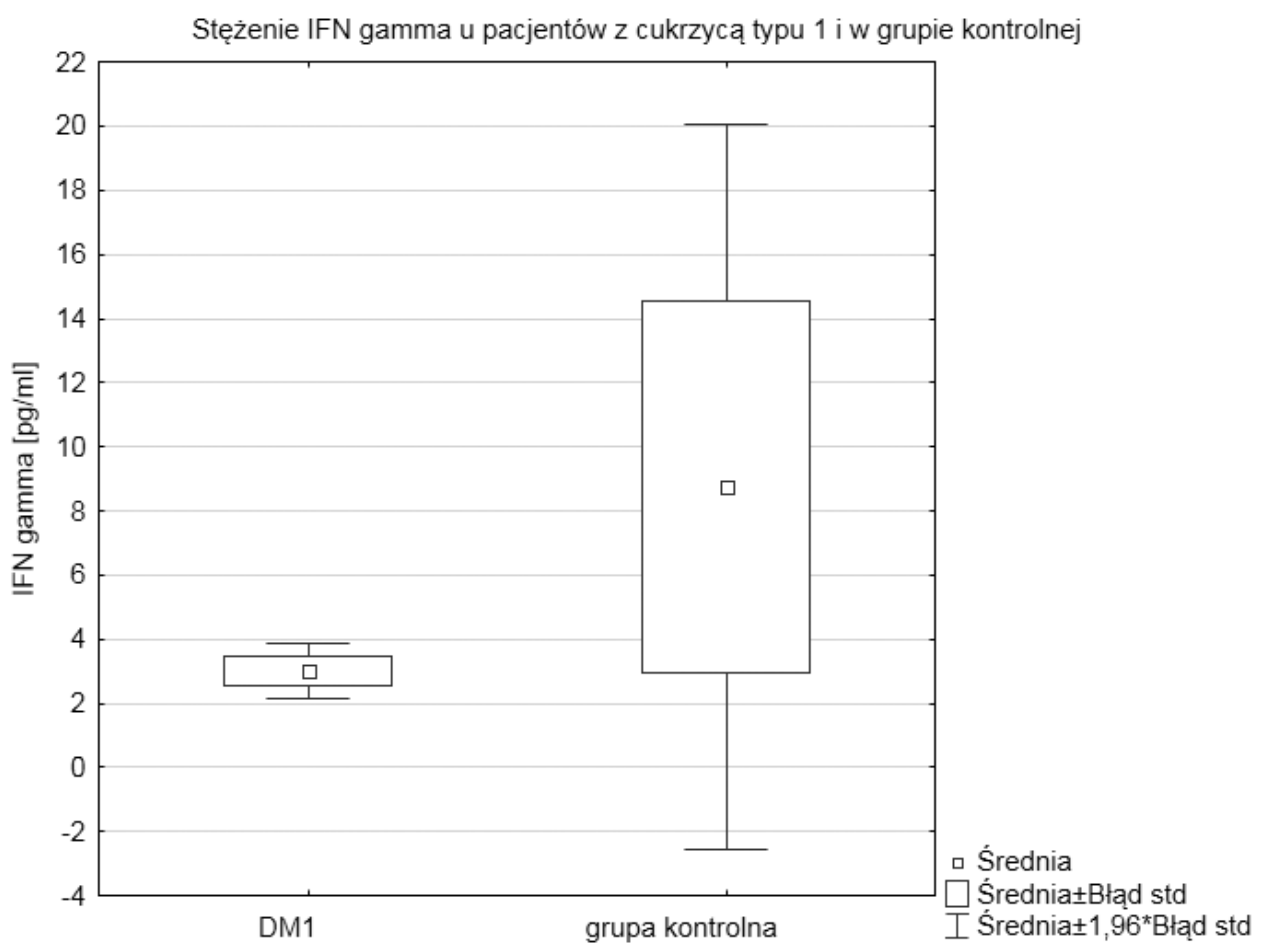

Ryc. 3. Stężenie IFN- $\gamma$ u pacjentów z cukrzycą typu 1 i w grupie kontrolnej

Fig. 3. Stężenie IFN- $\gamma$ concentration in patients with type 1 diabetes and in controls

Wykazano korelację CHEM ze stężeniem selektyny $\mathrm{E}(\mathrm{r}=0,4790, \mathrm{p}=0,024)$ oraz liczbą leukocytów ( $\mathrm{r}=0,4455, \mathrm{p}=0,038)$, a także ujemną korelację $\mathrm{z}$ wiekiem badanych $(\mathrm{r}=-0,29, \mathrm{p}=0,0232)$. Nie potwierdzono natomiast istotnej $(\mathrm{p}>0,05)$ korelacji stężenia CHEM z odsetkiem HbA1c, parametrami gospodarki lipidowej ani czasem trwania choroby.

W badanej grupie nie stwierdzono obecności retinopatii, zaś znamienną mikroalbuminurię wykazano u trzech pacjentów, u których stężenie CHEM było porównywalne do stężenia CHEM w grupie bez tego powikłania (odpowiednio 51,57 $\pm 2,03 \mathrm{ng}$ / $\mathrm{ml}$ vs. $55,43 \pm 10,21 \mathrm{ng} / \mathrm{ml}, \mathrm{p}=0,61)$.

\section{Dyskusja}

Historia badań nad chemeryną rozpoczęła się około 15 lat temu odkryciem jej roli jako czynnika chemotaktycznego dla komórek dendrytycznych i makrofagów [7]. Kilka lat później wykazano, że jest to także regulator metabolizmu adipocytów i adipogenezy, który wpływa na insulinowrażliwość $[15,16]$. Pojawiła się więc hipoteza o potencjalnej roli CHEM w rozwoju zespołu metabolicznego $[9,17]$. Wykazywano wielokrotnie, że stężenie

Agnieszka Zubkiewicz-Kucharska, Joanna Chrzanowska, Monika Seifert, Barbara Salmonowicz, Barbara Chrzanowska, tej cytokiny jest istotnie większe u pacjentów z otyłością, cukrzycą typu 2 i chorobą niedokrwienną serca [18-20]. CHEM było zależne nie tyle od BMI badanych, co od ilości tkanki tłuszczowej trzewnej $[21,22]$, a także - odwrotnie korelowało z insulinowrażliwością [23].Wysokie stężenie chemeryny może być markerem powikłań mikronaczyniowych cukrzycy - retinopatii i nefropatii [24,25].

Związek CHEM z glikemią i parametrami gospodarki lipidowej, jaki udowodniono u otyłych pacjentów z cukrzycą typu 2 [9], pozwalał założyć, że również w cukrzycy typu 1 cytokina ta będzie markerem toczącego się zapalenia, zależnego od wyrównania metabolicznego choroby. Nasze badanie nie potwierdza tej hipotezy. Stężenie CHEM u pacjentów z cukrzycą typu 1 nie różniło się istotnie od CHEM w grupie kontrolnej - dzieci z prawidłową masą ciała, bez zaburzeń gospodarki węglowodanowej i innych chorób autoimmunologicznych. Nie wykazano także związku chemeryny od czasu trwania cukrzycy, stopnia wyrównania metabolicznego (HbA1c), a także zachowanej insulinosekrecji czy obecności innych chorób z autoagresji. Wyniki uzyskane $\mathrm{w}$ badaniu własnym nie są spójne z wynikami innych ośrodków. Verrijn Stuart i Schipper z zespołem wykazali, że stę- 


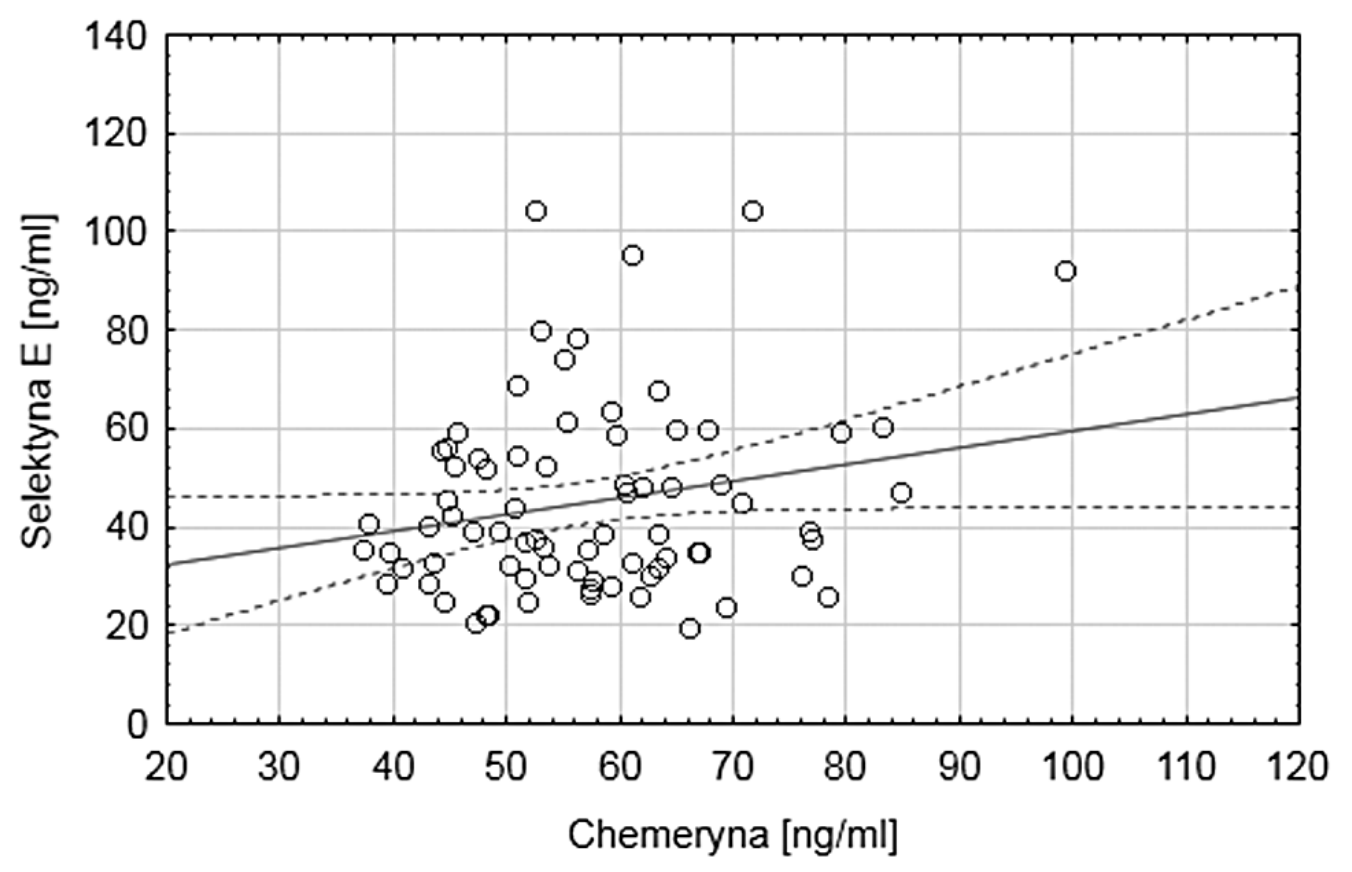

Ryc. 4. Korelacja chemeryny i selektyny E u pacjentów z cukrzycą typu 1

Fig. 4. Chemerin and E-selectin correlation in patients with type 1 diabetes

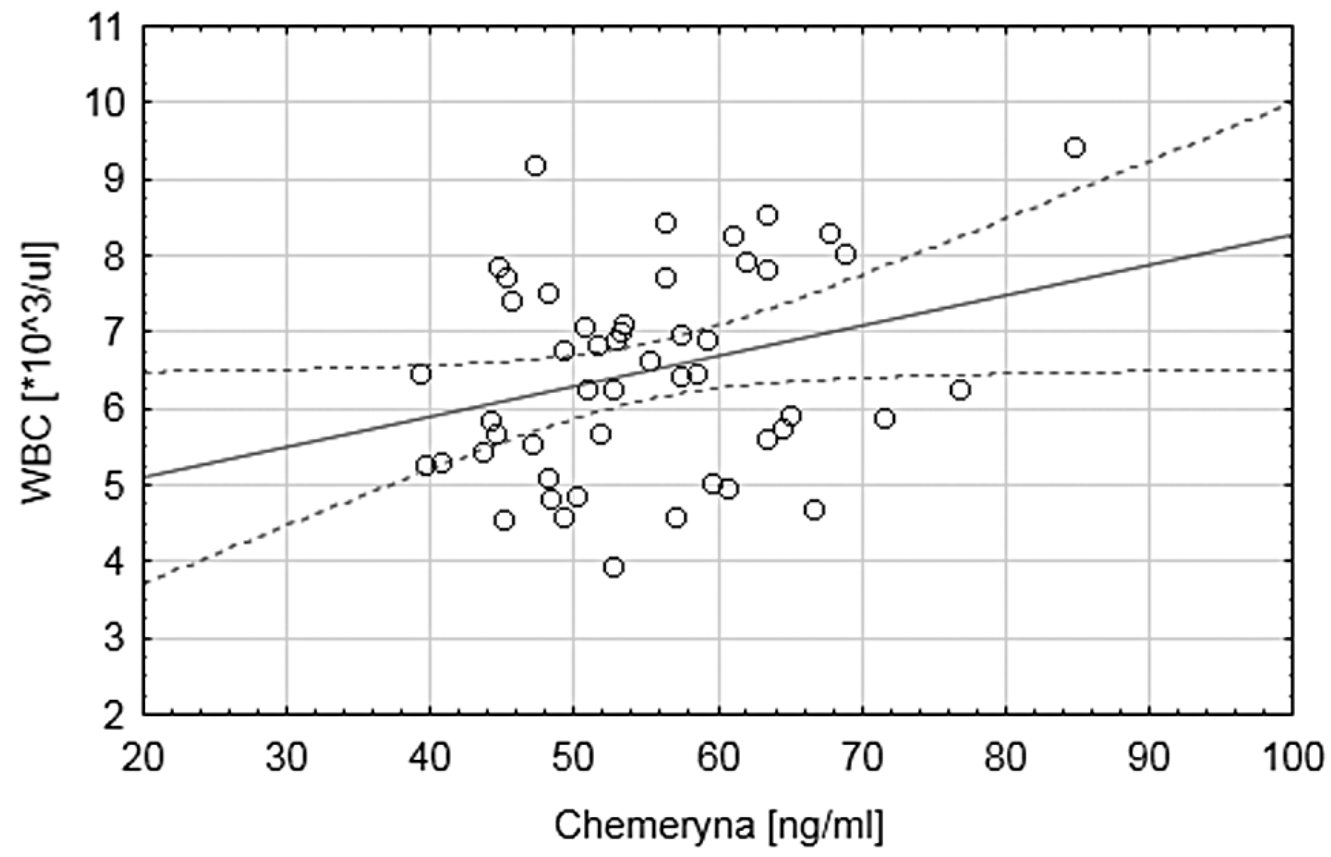

Ryc. 5. Korelacja chemeryny z liczbą leukocytów u pacjentów z cukrzycą typu 1

Fig. 5. Chemerin and leukocyte count correlation in patients with type 1 diabetes 
żenie chemeryny jest istotnie większe zarówno w cukrzycy nowo rozpoznanej, jak i trwającej powyżej roku w porównaniu z grupą kontrolną [12]. Grupa holenderska obejmowała jednak zaledwie dwadzieścioro dzieci z nowo rozpoznaną oraz dwadzieścioro dzieci z dłużej trwającą cukrzycą [12]. El Dayem i wsp. również stwierdzili istotnie większe stężenie CHEM u pacjentów z cukrzycą typu 1. Badani przez nich pacjenci byli starsi, na cukrzycę chorowali średnio 9 lat. Ponadto wykazali oni, że CHEM koreluje ze wskaźnikiem albumina/kreatynina (istotnie większym u pacjentów z cukrzycą w porównaniu do grupy kontrolnej), co odzwierciedla rolę tego białka w patogenezie powikłań mikronaczyniowych [13]. W badanej przez nas grupie jedynie u trojga chorych ustalono znamienną albuminurię, u pozostałych funkcja nerek była prawidłowa.

Redondo i wsp. potwierdzili istotnie większe stężenie tej cytokiny u otyłych pacjentów z cukrzycą typu $1 \mathrm{w}$ porównaniu do chorych z prawidłową masą ciała. Badana przez nich grupa obejmowała pięćdziesięcioro dzieci z cukrzycą typu 1, w tym osiemnaścioro otyłych. Wyników nie odnoszono do grupy kontrolnej bez zaburzeń gospodarki węglowodanowej [14]. W naszym materiale nie stwierdzono otyłości. Ponadto leptynemia i adiponekty- nemia były porównywalne u pacjentów z cukrzycą typu 1 i w grupie kontrolnej. Prawdopodobnie brak różnicy BMI spowodował, że nie wykazano także różnicy silnie skorelowanej z większą zawartością tkanki tłuszczowej w organizmie CHEM w badanych przez nas grupach. Niestety nie przeprowadzono oceny składu masy ciała, w tym nie oceniono zawartości tkanki tłuszczowej wisceralnej.

Chemeryna jest cytokiną silnie związaną ze stanem zapalenia. Nie dziwi wobec tego fakt istotnej korelacji jej stężenia ze stężeniami innych markerów zapalenia, jak np. selektyny E czy leukocytozy. Stężenia selektyny E, interferonu , leukocytoza i CRP nie wskazywały na istotnie większy stan zapalny u chorych w porównaniu ze zdrowymi dziećmi. Być może tłumaczy to brak różnicy stężenia CHEM u pacjentów z cukrzycą w porównaniu do grupy kontrolnej, jaki stwierdziliśmy w naszym materiale.

\section{Wniosek}

U pacjentów z cukrzycą typu 1 i prawidłową masą ciała nie wykazano związku CHEM z wyrównaniem metabolicznym i czasem trwania choroby.

\section{Piśmiennictwo / References}

1. Devaraj S., Dasu M.R., Jialal I.: Diabetes is a proinflammatory state: a translational perspective. Expert Rev. Endocrinol. Metab., 2010:5, 19-28.

2. Schalkwijk C.G., Poland D.C., van Dijk W., Kok A. et al.: Plasma concentration of $\mathrm{C}$-reactive protein is increased in type I diabetic patients without clinical macroangiopathy and correlates with markers of endothelial dysfunction: evidence for chronic inflammation. Diabetologia, 1999:42, 351-357.

3. Goldberg R.B: Cytokine and cytokinelike inflammation markers, endothelial dysfunction, and imbalanced coagulation in development of diabetes and its complications. J. Clin. Endocrinol. Metab., 2009:94, 3171-3182.

4. Hotamisligil G.S.: Inflammation and metabolic disorders. Nature, 2006:444, 860-867.

5. Ouchi N., Parker J.L., Lugus J.J., Walsh K.: Adipokines in inflammation and metabolic disease. Nat. Rev. Immunol., 2011:11, 85-97.

Agnieszka Zubkiewicz-Kucharska, Joanna Chrzanowska, Monika Seifert, Barbara Salmonowicz, Barbara Chrzanowska, Anna Noczyńska
6. Dandona P., Aljada A., Chaudhuri A. et al.: Metabolic syndrome: a comprehensive perspective based on interactions between obesity, diabetes, and inflammation. Circulation, 2005:111, 1448-1454

7. Wittamer V., Franssen J.D., Vulcano M., Mirjolet J.F. et al.: Specific recruitment of antigen-presenting cells by chemerin, a novel processed ligand from human inflammatory fluids. J. Exp. Med., 2003 Oct:6, 198(7), 977985.

8. Sell H., Laurencikiene J., Taube A., Eckardt K. et al.: Chemerin Is a Novel Adipocyte-Derived Factor Inducing Insulin Resistance in Primary Human Skeletal Muscle Cells. Diabetes, 2009 Dec:58(12), 2731-2740.

9. Stejskal D., Karpisek M., Hanulova Z., Svestak M.: Chemerin is an independent marker of the metabolic syndrome in a caucasian population a pilot study. Biomed. Pap. Med. Fac. Univ. Palacky Olomouc Czech Repub., 2008:152(2), 217-221.

Endokrynol. Ped. 2017.16.2.59.87-94
10. Rourke J.L., Dranse H.J., Sinal C.J.: Towards an integrative approach to understanding the role of chemerin in human health and disease. Obes. Rev., 2013:14, 245-262. doi:10.1111/ obr.12009.

11. Weigert J., Neumeier M., Wanninger J., Filarsky M. et al.: Systemic chemerinis related to inflammation rather than obesity in type 2 diabetes. Clinical Endocrinology, 2010:72, 342-348.

12. Verrijn Stuart A.A., Schipper H.S., Tasdelen I., Egan D.A. et al.: Altered plasma adipokine levels and in vitro adipocyte differentiation in pediatric type 1 diabetes. J. Clin. Endocrinol. Metab., 2012 Feb:97(2), 463-472. doi: 10.1210/jc.2011-1858.

13. El Dayem S.M., Battah A.A., El BohyAel M. et al.: Relationship of plasma level of chemerin and vaspin to early atherosclerotic changes and cardiac autonomic neuropathy in adolescent type 1 diabetic patients. J. Pediatr. Endocrinol. Metab., 2015 Mar:28(3- 
4), 265-273. doi: 10.1515/jpem-20140215.

14. Redondo M.J., Rodriguez L.M., Haymond M.W., Hampe C.S. et al.: Serum adiposity-induced biomarkers in obese and lean children with recently diagnosed autoimmune type 1 diabetes. Pediatr. Diabetes., 2014 Dec:15(8), 543-549. doi: 10.1111/pedi.12159.

15. Goralski K.B., McCarthy T.C., Hanniman E.A., Zabel B.A. et al.: Chemerin, a novel adipokine that regulates adipogenesis and adipocyte metabolism. J. Biol. Chem., 2007 Sep:21, 282(38), 28175-28188.

16. Takahashi M., Takahashi Y., Takahashi K., Zolotaryov F.N. et al.: Chemerin enhances insulin signaling and potentiates insulin-stimulated glucose uptake in 3T3-L1 adipocytes. FEBS Lett., 2008 Mar:5, 582(5), 573-578. doi: 10.1016/j. febslet.2008.01.023.

17. Bozaoglu K., Bolton K., McMillan J., Zimmet P. et al.: Chemerin is a novel adipokine associated with obesity and metabolic syndrome. Endocrinology, 2007 Oct:148(10), 4687-4694.

18. İnci S., Aksan G., Doğan P.: Chemerin as an independent predictor of cardiovascular event risk. Ther. Adv. Endocrinol. Metab.. 2016 Apr:7(2), 57-68. doi: 10.1177/2042018816629894.

19. Rourke J.L., Dranse H.J., Sinal C.J.: Towards an integrative approach to understanding the role of chemerin in human health and disease. Obes. Rev., 2013 Mar:14(3), 245-262. doi: 10.1111/obr.12009. Epub 2012 Dec 6.

20. Lu B., Zhao M., Jiang W., Ma J. et al.: Independent Association of Circulating Level of Chemerin With Functional and Early Morphological Vascular Changes in Newly Diagnosed Type 2 Diabetic Patients. Medicine (Baltimore), 2015 Nov:94(47), e1990. doi: 10.1097/ MD.0000000000001990.

21. Cheon D.Y., Kang J.G., Lee S.J., Ihm S.H. et al.: Serum Chemerin Levels are Associated with Visceral Adiposity, Independent of Waist Circumfer- ence, in Newly Diagnosed Type 2 Diabetic Subjects. Yonsei Med. J., 2017 Mar:58(2), 319-325. doi: 10.3349/ ymi.2017.58.2.319.

22. Zylla S., Pietzner M., Kühn J.P., Völzke $\mathrm{H}$. et al.: Serum chemerin is associated with inflammatory and metabolic parameters-results of a populationbased study. Obesity (Silver Spring), 2017 Feb:25(2), 468-475. doi: 10.1002/ oby. 21735

23. Leiherer A., Muendlein A., Kinz E., Vonbank $A$. et al.: High plasma chemerin is associated with renal dysfunction and predictive for cardiovascular events Insights from phenotype and genotype characterization. Vascul. Pharmacol., 2016 Feb:77, 60-68. doi: 10.1016/j. vph.2015.08.010.

24. Du J., Li R., Xu L., Ma R., Liu J. et al.: Increased Serum Chemerin Levels in Diabetic Retinopathy of Type 2 Diabetic Patients. Curr Eye Res., 2016:41(1), 114-120. doi: 10.3109/02713683.2015.1004718. 